\title{
Pátio do Colégio, Largo do Palácio
}

Solange Ferraz de Lima

Museu Paulista da USP
Pátio do Colégio integra, desde há muito, o conjunto de espaços qualificados como patrimônio cultural, ' e a história de sua edificação e usos nos últimos 100 anos encerra as marcas de modos distintos de apropriação da cidade. Proponho aqui um exercício de leitura da trajetória deste espaço a partir de um conjunto iconográfico que reúne cartões postais e álbuns fotográficos.

A análise empreendida abarca níveis distintos de interpretação da relação espaço urbano-documento visual. Em seu nível mais imediato, estes documentos visuais informam sobre as transformações na configuração espacial edifício e seu entorno - do Pátio do Colégio. Para o presente artigo não nos deteremos neste aspecto, visto que o conjunto iconográfico em questão não acrescenta à trajetória de transformações físicas nenhum dado que já não seja conhecido.

Partindo do pressuposto de que a produção iconográfica de paisagens urbanas é parte integrante e ativa da produção social da cidade, uma primeira aproximação pretende chamar a atenção para o potencial dos documentos visuais em sinalizar, de maneira específica e própria, processos diferenciados de apropriação espacial. Neste sentido, serão analisados aspectos da composição formal de uma série de cartões postais relativos ao Pátio do Colégio. Certas opções formais, voluntárias ou involuntárias, podem ser entendidas como sintomáticas das transformações sofridas por este espaço público. Em outro patamar, será enfocada a circulação de determinadas imagens do pátio a fim de explicitar seu papel como vetores de ações e discursos instituídos no campo das representações sociais urbanas. Vale ressaltar que esta análise não se restringe somente à exploração de documentos iconográficos, mas integra também descrições textuais cuja construção semântica tem como elemento estruturador a visualidade.

\footnotetext{
1. Sobre a problemática noção de patrimônio cultural, ver André Chastel. La notion de Patrimoine. In: NORA, Pierre (Org.). Les lieux de memoire, $\mathrm{v} . \mathrm{II}$ - La Nation. PARIS: Gallimard, 1986. Neste artigo, Chastel analisa a evolução do termo patrimônio e os sentidos sociais e políticos a ele associados. Na verdade, apesar do termo ser antigo (é um termo romano que designa patrimônio pertencente a uma família, objeto de herança, tal como utilizado juridicamente), ele passou a ser empregado, nos últimos dois séculos, como uma noção global e até certo ponto vaga. Nesta categoria incluem-se desde objetos, lendas, edifícios e até mesmo a língua, ou seja, dimensões do tangivele do intangível. Esta noção de patrimônio está associada a valores afetivos e designa classe de coisas consideradas fundamentais para a existência nacional e humana. Seu uso corrente também nos remete à pró-
} 
pria evolução das noções de nacional e nacionalismo e à função de perpetuação de marcas capazes de fornecer identidades coletivas, nacionais.

2. Correspondências entre jesuítas, relatos de historiadores da virada do século, viajantes e homens públicos. Cf. número especial sobre o Pátio do Colégio da revista do Arquivo Municipal, v. 187, jan.-dez. 1975.

3. Sobre a museologia e as encomendas para a exposição histórica concebida por Taunay para o Centenário da Independência, em 1922, cf. Ana
Imagens-sintoma

A conformação espacial do pátio, das dependências internas e fachada do colégio nos séculos XVII e XVIII nos é relatada por documentos textuais ${ }^{2}$. Segundo fontes escritas, a reconstrução da fachada e a construção da torre, que persistiu até 1896, aconteceram por iniciativa de duas "paulistas ilustres" - $d$. Angela de Siqueira e d. Leonor de Siqueira - que financiaram as obras em 1681 (MELL; MELLO, 1975). Parece ter sido esta a feição com que o colégio chegou ao século XIX, quando Thomas Ender o desenhou, em 1818 , constituindo o primeiro registro iconográfico do Pátio do Colégio conhecido dos estudiosos da história da cidade. Este registro tornou-se mais difundido a partir de sua reprodução em óleo sobre tela encomendada por Affonso de Escragnolle Taunay a Wasth Rodrigues no início da década de 1920, para compor uma das salas da exposição histórica do Museu Paulista ${ }^{3}$.

Odesenho de Thomas Ender feito em 1818 (FIGURA 1) e a descrição de Saint Hilaire datada de $1819^{4}$ nos fornecem uma imagem urbana que

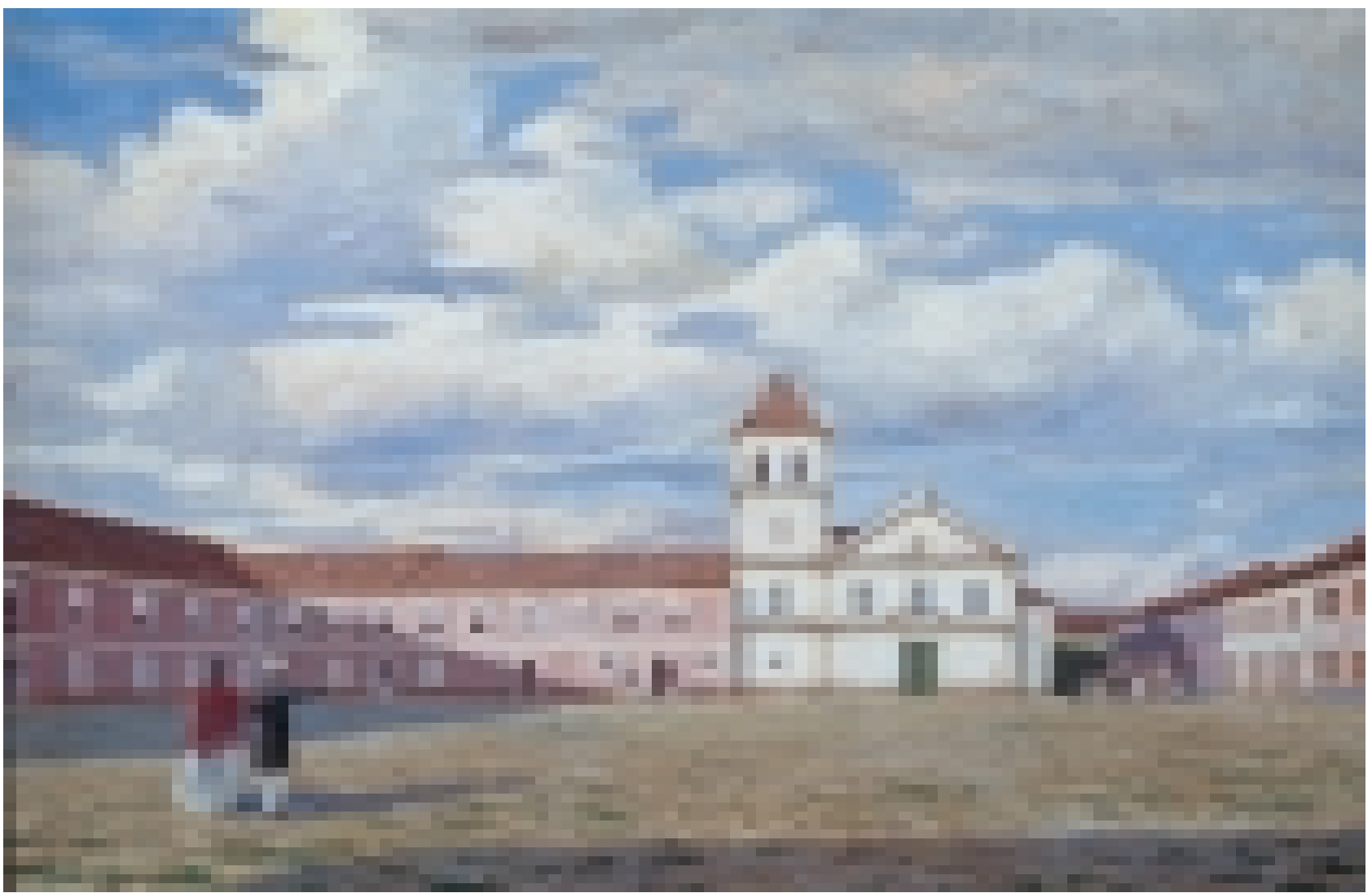


associa de maneira consistente a configuração formal e o significado social e funcional desse espaço. A perspectiva frontal e o enquadramento escolhidos por Ender salientam um aspecto fundamental do Pátio do Colégio - o vazio constituído pelas fachadas em forma de L da igreja e do colégio. Ender posiciona as edificações no plano médio, de modo a ocuparem mais de três quartos da extensão horizontal do quadro e destaca, em primeiro plano, a pavimentação de pedra do pátio. O arranjo formal amplia o âmbito de domínio espacial do edifício, configurando visualmente uma das principais características das edificações jesuíticas, a saber, a delimitação de um campo aberto de ação.

palácio:

Saint Hilaire também destaca esta característica ao descrever o

A posição do Palácio é tão bem escolhida quanto a de todos os edifícios construídos pelos jesuítas no Brasil. Elevado em uma das extremidades da cidade, está ligado à mesma por sua fachada, que forma dois dos lados de uma pequena praça quadrada. Os seus fundos dão para o campo [...] Quem se posta nas janelas do palácio, do lado que dá para o campo, desfruta de vista deliciosa, a da planície que já descrevi. Abaixo da cidade vê-se o Tamanduateí, que desliza sinuoso pelo campo em parte coberto de água e além do qual estende-se pastagens em que se apresentam aqui e ali, tufos de mato pouco elevados. À esquerda, a noroeste, o horizonte é limitado pelas montanhas do Jaraguá, que descrevem um semicírculo. À direita, a planície estende-se ao longe, atravessada pelo caminho do Rio de Janeiro, que é margeado por chácaras. Rebanhos de gado pastam nos campos e a paisagem é animada pelas tropas que chegam à cidade, pelas que saem e pelo grande número de mulheres que lavam roupa à beira do ribeirão. (SAINT HILAIRE, 1819 apud BRUNO, 1981).

Os aspectos visuais deste espaço são enfatizados por Saint Hilaire. A importância atribuída à aparência é perceptível na referência à fachada como elemento de ligação entre a cidade e a praça quadrada. Por outro lado, a cidade - e particularmente o palácio - é plataforma de observação - "Quem se posta nas janelas do palácio, do lado que dá para o campo, desfruta de vista deliciosa." A vista proporciona uma observação cuidadosa que se inicia com a topografia, caracteriza a vegetação, estabelece os limites físicos para voltar ao aspecto topográfico, e só então inserir a ação humana produtiva, inferida pela presença das chácaras e dos rebanhos que pastam, a circulação social e o trabalho, as tropas que chegam à cidade e as mulheres que lavam roupa. Ao se deter nesta observação, Saint Hilaire dá conta de explicitar a localização estratégica da construção jesuítica no controle de uma parte considerável e de importância da cidade - os arredores e a principal via de ligação com a capital do Império.

Assim, sobre o Pátio do Colégio e o Palácio do Governo no início do século XIX temos já como elementos-chave da dimensão material e visual de sua implantação o domínio da observação e das relações espaciais imposto pela expansão da edificação na forma de uma arena aberta.

A partir da disseminação da prática fotográfica no Brasil, os registros se difundem. No início da década de 1860 surgem as primeiras fotografias do pátio, dentre elas, a mais conhecida, de autoria de Militão Augusto de Azevedo. No álbum que organiza 25 anos depois, Militão identifica o centro administrativo e político de São Paulo com legenda que nos revela a
Claudia Brefe. Um lugar de memória para a nação; O Museu Paulista reinventado por Affonso d'Escragnolle Taunay (1917-1945). Campinas, Unicamp, 1999 (Doutorado) e Carvalho; Lima, São Paulo Antigo, uma encomenda da modernidade: as fotografias de Militão nas pinturas do Museu Paulista.Anais do Museu Paulista Revista de História e Cultura Material. São Paulo, v. 1, p. 147174, 1993.

4.Augustin François César Prouvençal Saint Hilaire (1779-1853) foi um dos muitos viajantes que vieram ao Brasil com a missão específica de coletar informações sobre a topografia, fauna e flora brasileiras. Saint Hilaire chegou ao Brasil em $1816 \mathrm{e}$ viajou pelas cidades brasileiras até 1843 . Esteve no Rio de Janeiro, Espírito Santo, Minas Gerais, Goiás, Mato Grosso, São Paulo, Paraná, Santa Catarina e Rio Grande do Sul.Seus inúmeros relatórios de viagem não se restringem tão-somente aos aspectos naturais, embora este fosse o seu primeiro interesse, mas abarcam aspectos da vida social, econômica e política do Brasil Imperial. Sua obra Viagem à Província de São Paulo contempla uma breve história da província, dados geográficos e uma descrição dos costumes e aspectos gerais da cidade em 1819 (SaintHilaire, Auguste de. Viagem à Província de São Paulo. São Paulo: Edusp, 1976). 
5. Eusébio Stevaux, francês radicado no Brasil, foi o engenheiro arquiteto responsável pelas reformas de inúmeros edifícios públicos no final da década de 1870 . Sua obra, pouco conhecida, foi analisada por Eudes Campos (Palacetes paulistanos: a evolução do ambiente doméstico sob o Império. Historical Archeology in Latin America, Columbia,USA, n. 6, p. 89103, jan., 1995).

6. Sobre o repertório de temas enfocados pela fotografia de São Paulo circulada em álbuns, cf. Solange Ferraz de Lima e concentração de atividades e, por isso, a importância deste local para a cidade (FIGURA 2): Igreja e Convento do Collegio servindo de Palacio do Governo, Thesourarias Geral e Provincial, Assembleia Provincial, Collectoria e Correio (edificação dos jesuítas em 1673).

Reciclado no seu uso ao ser destinado às atividades do poder público desde 1776, pouco depois da expulsão dos jesuítas, o edifício sofreu as primeiras reformas para ser a sede do governo de Morgado Mateus. Essas alterações, no entanto, pouco modificaram a tachada e o entorno, que continuaram conformando esse espaço tão peculiar do período colonial, sem vegetação e cujos limites eram dados pelas construções. Em seu Álbum Comparativo, Militão optou por registrar - local em 1862, precisamente durante uma celebração cívica. Nesta imagem, diferentemente daquela desenhada por Ender, o ponto de vista escolhido graças ao posicionamento do fotógrafo, provavelmente do alto de uma sacada ou janela, nos oferece uma visão bem mais completa do espaço aberto formado pela construção em $L$, com destaque para o palácio e a festividade que se desenrola em seu pátio. Mais uma vez, é o espaço aberto que ganha relevância, graças à presença do corpo policial da província e à assistência.

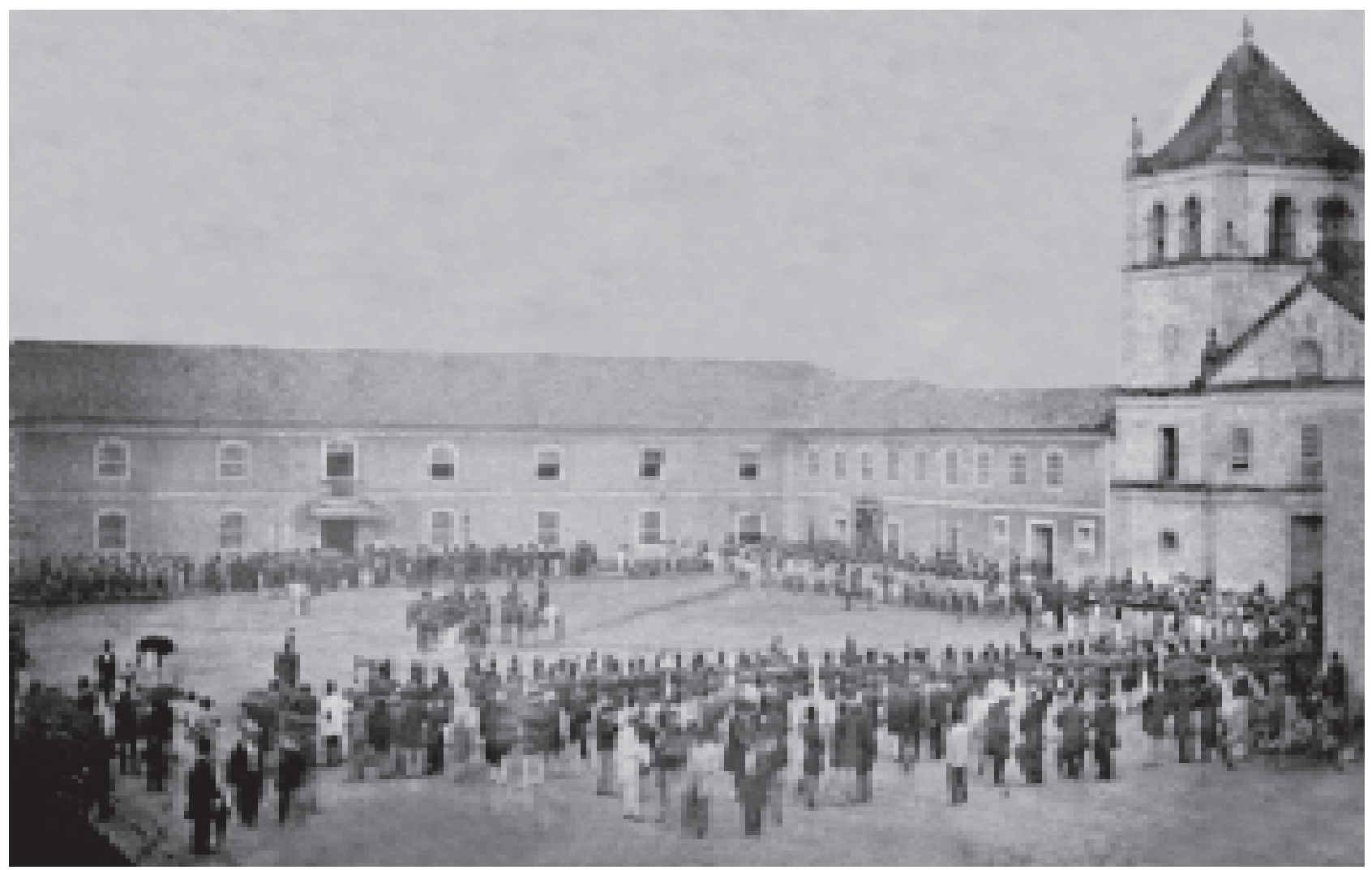

FIGURA 2 - Pátio do Colégio, 1862, albumina de Militão A. de Azevedo. Álbum Comparativo da Cidade de São Paulo - 1862/887. Acervo Museu Paulista da USP. Reprodução de José Rosael. 
Em fins do século XIX, a edificação denominada Palácio do Governo teve a ala perpendicular à igreja derrubada, e a ala contígua ganhou uma fachada em estilo neoclássico na sua entrada principal. A reforma, projetada pelo engenheiroarquiteto Stevaux ${ }^{5}$, foi registrada em 1881 também por Militão, em momento anterior à transformação urbanística do pátio em praça (FIGURA 3). $\bigcirc$ registro da nova fachada é de uma perspectiva frontal, bem diferente da imagem de 1862. Aqui, a intenção era claramente documentar a transformação. Mas este tipo de enquadramento - frontal, assemelhado aos desenhos arquitetônicos de fachada -, que se tornara corrente na virada do século XIX para o XX nos registros dos edifícios públicos de arquitetura eclética ${ }^{6}$, não caracteriza a maioria das imagens do palácio e do Pátio do Colégio. No caso, a "praça quadrada" que recebe tratamento paisagístico em meados da década de 1880 continua foco de maior atenção.

Duas imagens em fototipia, de autoria desconhecida mas datadas, respectivamente, de 1889 e 1891 (FIGURA 4), dão continuidade à abordagem visual valorativa do entorno da edificação do palácio. A perspectiva escolhida pelo fotógrafo é semelhante àquela de Militão no seu registro de 1862, de modo a abarcar em primeiro plano a praça, e em plano médio a igreja e o palácio.

Visualmente, a justaposição das fachadas neoclássica do corpo lateral e vernacular da capela expressa exemplarmente o processo de múltiplas apropriações de um espaço e de reciclagem de seu uso. As transformações na área aberta indicam os intuitos disciplinares característicos da racionalidade urbana.
Vânia Carneiro de Carvalho. Fotografia e Cidade: da razão urbana à lógica do consumo. Campinas: Mercado de Letras, 1997.

7. Sobre a história da Academia de Direito na cidade de São Paulo, cf. Ana Luisa Martins e Heloisa Barbuy. Arcadas: história da Faculdade de Direito do Largo de São Francisco 1827-1997. São Paulo: Alternativa Serviços Programados, 1998.

8. Sobre a vida e obra de Guilherme Gaensly, inclusive seus contratos com o poder público, cf. Vera Maria de Barros Ferraz (Org.). Imagens de São Paulo: Gaensly no acervo da Light, 1899-1925 e Boris Kossoy. São Paulo, 1900. São Paulo: CBPO/ Kosmos, 1988.

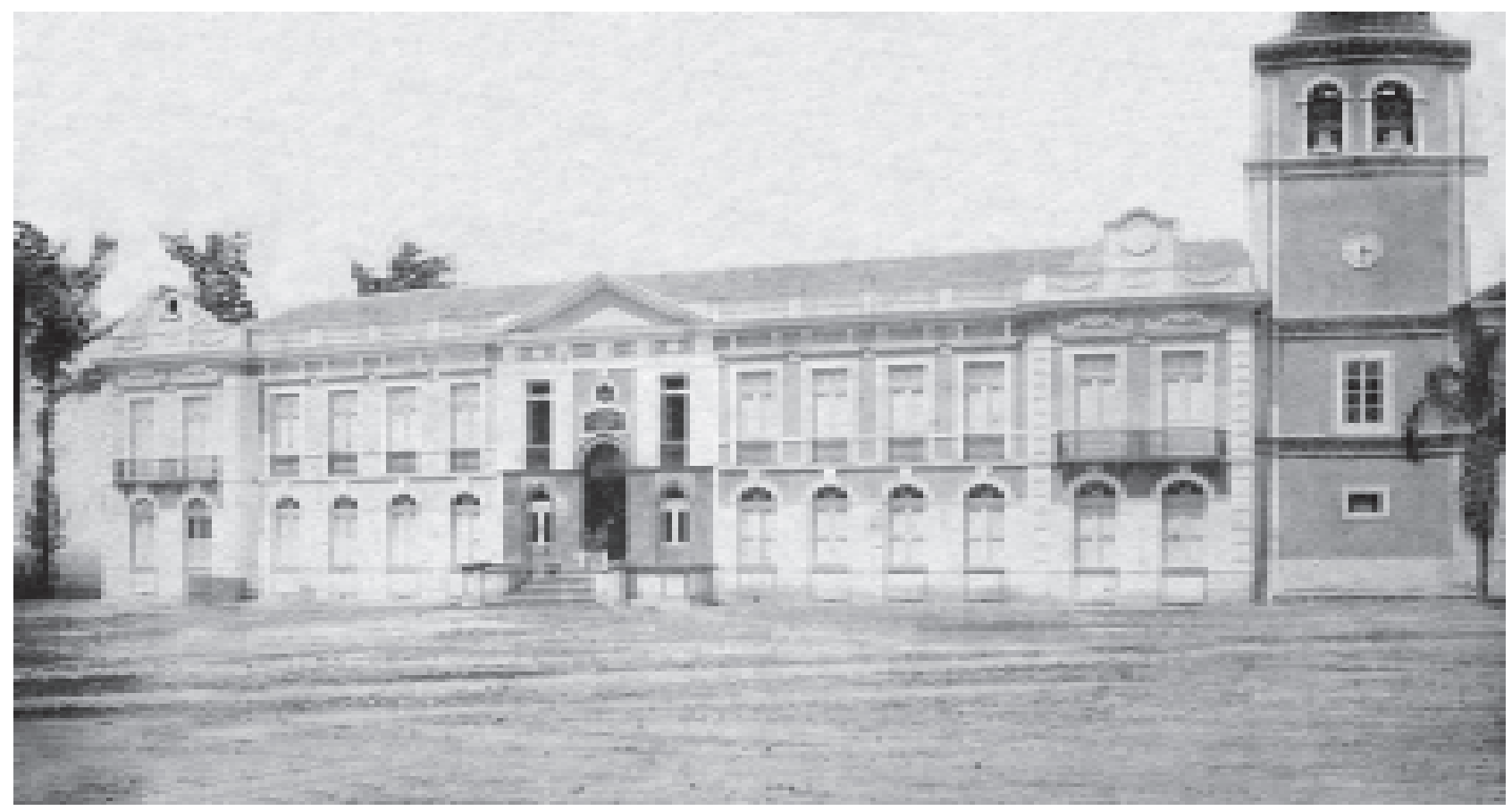

FIGURA 3 - Pátio do Colégio, c. 1881, albumina de Militão Augusto de Azevedo. Acervo Museu Paulista da USP. Reprodução de José Rosael. 
9. O correspondente ao Palácio do Governo do Pátio do Colégio seria o palácio localizado no alto do Morumbi, cujos jardins têm escala para automóveis, e a segurança mantém os cidadãos comuns afastados centenas de metros de seu entorno imediato.

10. Para montar as salas dedicadas à antiga iconografia paulista,Taunay (di-
A delimitação espacial pelo gradil de ferro materializa os dispositivos de controle. Desenha-se a praça e definem-se os lugares: o coreto para a banda, os bancos para sentar, o gradil que isola, e finalmente um caminho que orienta o fluxo de transeuntes. Nesse momento, o Pátio do Colégio representa o espaço de gerência da cidade pelo Estado, e ainda guarda as funções religiosas. $\bigcirc$ espaço aberto transformado em praça torna-se o lugar para circular, ver e ser visto, cumprindo assim suas funções de sociabilidade.

Os relatos de fins do século XIX de Almeida Nogueira e de Jorge Americano são como uma espécie de complemento textual da fotografia de 1891 :

Erguia-se, ao lado, contígua ao Palácio, a veneranda igreja do Colégio, onde doutrinou Anchieta. Nela se celebrava, aos domingos, a missa do meio dia, a missa chique,

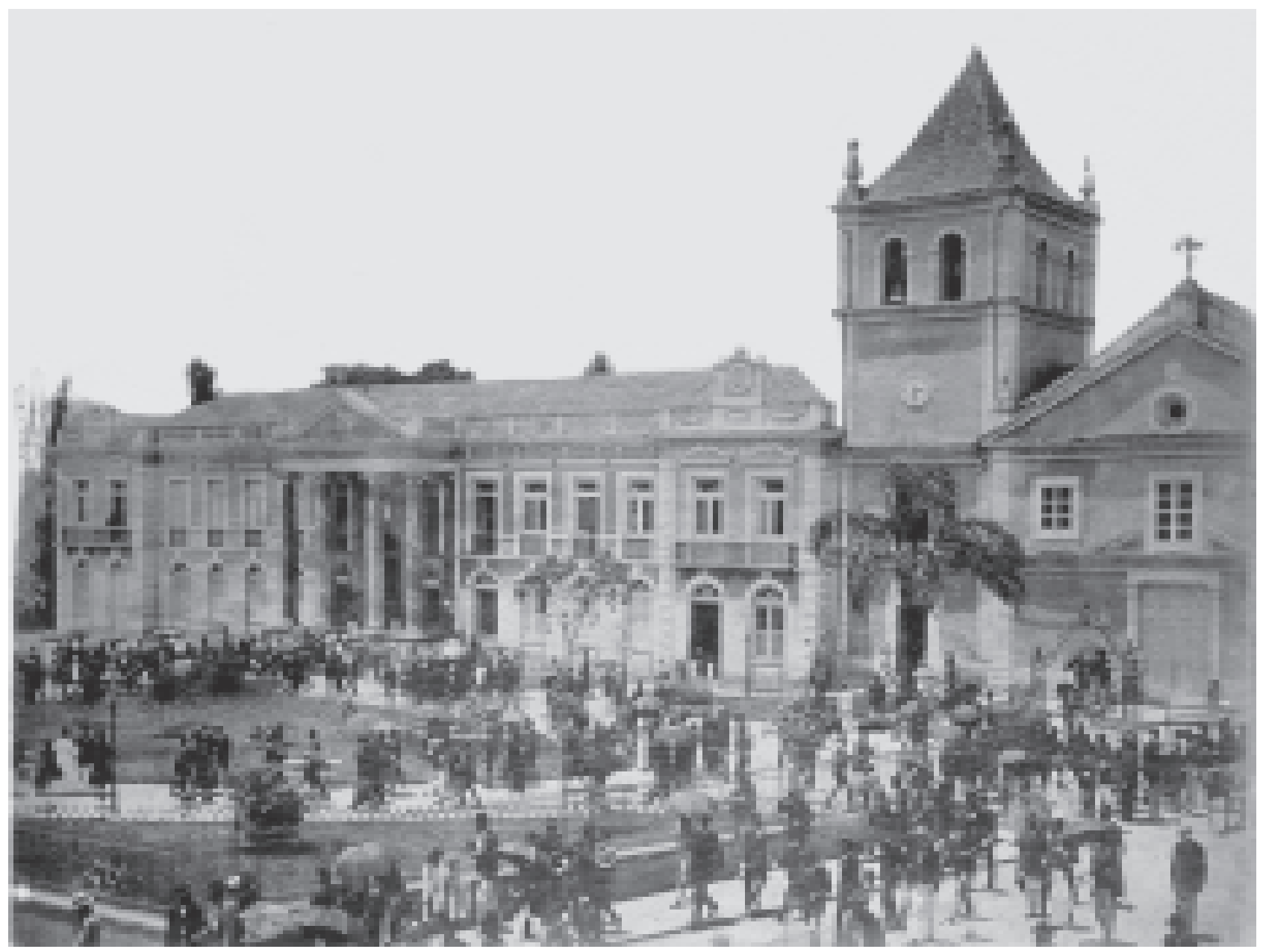


freqüentada pelo high-life paulistano, pela haute-gomme da Academia e pelas mais belas mundanas da cidade. De uma tribuna que se comunicava com o Palácio, ouviam a missa o presidente da província e sua família. (ALMEIDA NOGUEIRA, 1869-1874 apud BRUNO, 19811.

A banda da Força Pública [...] dava dois concertos por semana, às quintas-feiras no jardim do Palácio [...] O Pátio do Colégio constituía o Jardim do Palácio, cercado de grades com dois portões abertos. No lugar de onde parte o viaduto Boa Vista, ficava o coreto, em forma de concha acústica voltada para o jardim... Terminado o jantar, às cinco, as famílias dos bairros vinham vindo. Sentavam nos bancos do jardim. Os vadios eram escorraçados e ficavam para o lado de fora das grades. UORGE AMERICANO, 1898-1902 apud BRUNO, 19811 .

As imagens construídas por estes relatos qualificam um espaço com alto grau de sociabilidade, com múltiplas funções, um lugar de multifacetadas apropriações porque compartilhado por grupos e segmentos diferenciados socialmente. Almeida Nogueira destaca a igreja, e ao descrever suas funções elenca, de forma hierárquica, os diferentes grupos sociais que freqüentavam a missa mais importante - começa nomeando a elite (o high-life paulistano), em seguida os estudantes, para finalizar com as mundanas. É interessante notar como - autor diferencia os estudantes, sintoma de que a presença da Academia de Direito havia dado uma nova dinâmica à cidade?. Almeida Nogueira inicia e encerra este trecho referenciando a ligação entre o palácio e a igreja - a justaposição das fachadas contíguas e a comunicação que a tribuna estabelecia entre ambos, permitindo que o presidente ouvisse a missa. Desta forma, o autor sinaliza a importância simbólica e política de ocupação deste espaço pelo Clero e Estado, remetendo à sua configuração material e apropriação social.

Na descrição de Jorge Americano nota-se também a preocupação em discriminar os usuários deste lugar. Aqui, o autor explicita claramente o processo de transformação material - "O Pátio do Colégio constituía o Jardim do Palácio" e uma leitura mais crítica já permite ver nessa construção o início do processo de apagamento de um dos sinais físicos da ocupação espacial pelos jesuítas. Cronologicamente, é o jardim do palácio que passa a constituir o Pátio do Colégio e não o contrário, pois na verdade este se forma por sobre aquela "praça quadrada" descrita por Saint Hilaire. Se Almeida Nogueira se detém em uma atividade - a missa -, Jorge Americano nos informa de outra, os concertos da Banda da Força Pública. Também para essa atividade Jorge Americano enumera, de forma hierarquizada, os grupos sociais presentes, e o gradeamento da praça é claramente indicado como dispositivo de controle regulador dos usos entre incluídos e excluídos sociais. Sintoma de uma sociedade que se torna complexa, para a qual a gerência urbana precisa, materialmente, distinguir, discriminar, separar e controlar seus agentes. Neste breve trecho, fica claro tratar-se de uma rememoração do autor. A descrição dos lugares da praça inclui momento posterior - No lugar de onde saía o viaduto Boa Vista ficava o coreto [...]. E, neste caso, temos a pista de um processo de transformação urbana que privilegia a circulação, mas que na virada do século XIX para o XX ainda não se enunciara materialmente.

Se atentarmos para a legenda da imagem de 1891, é curioso notar que a menção ao Pátio do Colégio desaparece. A fotografia é identificada como Palácio do Governo. A designação do espaço em legendas ou nas descrições textuais de época é sintomática de um processo inicial de esvaziamento de funções e usos sociais. Na série de cartões postais, as legendas também apontam para o retor do Museu Paulis-ta entre 1917 e 1945) encomendou a diversos pintores acadêmicos cenas urbanas copiadas de fotografias e desenhos de viajantes. Wasth Rodrigues, um dos documentalistas da arquitetura colonial na época, fez diversos quadros para o museu, entre eles a vista do Pátio do Colégio, baseada em desenho de Thomas Ender. Nessa recriação da capital paulista, Taunay privilegia os aspectos formais e temáticos capazes de arcaizar a cidade: carros de boi substituem nas telas as carruagens presentes nas fotografias, damas de sombrinha são substituídas por tropeiros na representação pictórica, a aparência ensolarada na escolha das cores presente nas telas de Wasth Rodrigues é associada com a natureza autenticamente tropical e nacional Solange Ferraz de Lima e Vânia Carneiro de Carvalho.São PauloAntigo, uma encomenda da modernidade: as fotografias de Militão nas pinturas do Museu Paulista. Anais do Museu Paulista Revista de História e Cultura Material. São Paulo, v. 1, p. 147-174, 1993) 
desaparecimento, gradual, da denominação Pátio do Colégio, ou qualquer menção à igreja. Dos seis cartões postais circulados entre a década de 1890 e 1910 que integram o acervo do Museu Paulista, apenas um traz a imagem e identificação da igreja, provavelmente em data anterior a 1896. Os demais cartões, na sua maioria de autoria de Guilherme Gaesnly, trazem legendas que destacam o Largo do Palácio ou o Jardim do Palácio e, em menor escala, o Palácio do Governo. $\bigcirc$ mesmo acontece com as imagens que integram os álbuns fotográficos circulados no período.

Agora transformado em Jardim do Palácio, o espaço antes denominado Pátio do Colégio continua sendo valorizado nas tomadas fotográficas. $\bigcirc$ cartão postal intitulado Jardim do Palácio, de Guilherme Gaensly (circulado em 1902), é exemplar do tipo de enquadramento adotado (FIGURA 5). A imagem de Gaensly apresenta um equilíbrio dinâmico graças às ressonâncias formais entre os grupos de pessoas sentadas ou em pé que pontuam o primeiro plano e o plano médio. Em primeiríssimo plano, no quadrante inferior esquerdo, os bancos do jardim com exclusiva presença masculina. A sombra que cai sobre o grupo sentado impede que este seja o ponto central da fotografia. Por contraste, o olhar é encaminhado para o plano médio, em cujo centro posam três homens fardados de branco, definindo a área mais luminosa da imagem. $\bigcirc$ triângulo formado pela perspectiva diagonal adotada pelo fotógrafo finaliza no quadrante inferior à direita, também com um grupo de homens, parte sentado, parte em pé. Os edifícios do palácio e da Secretaria da Agricultura conformam o último plano, criando uma barreira que visualmente sugere uma continuidade plástica entre as fachadas de ambos. $\bigcirc$ centro geométrico, onde se encontram os homens fardados, é reforçado pelo torreão do palácio, elemento que atua, assim, como polarizador formal da imagem.

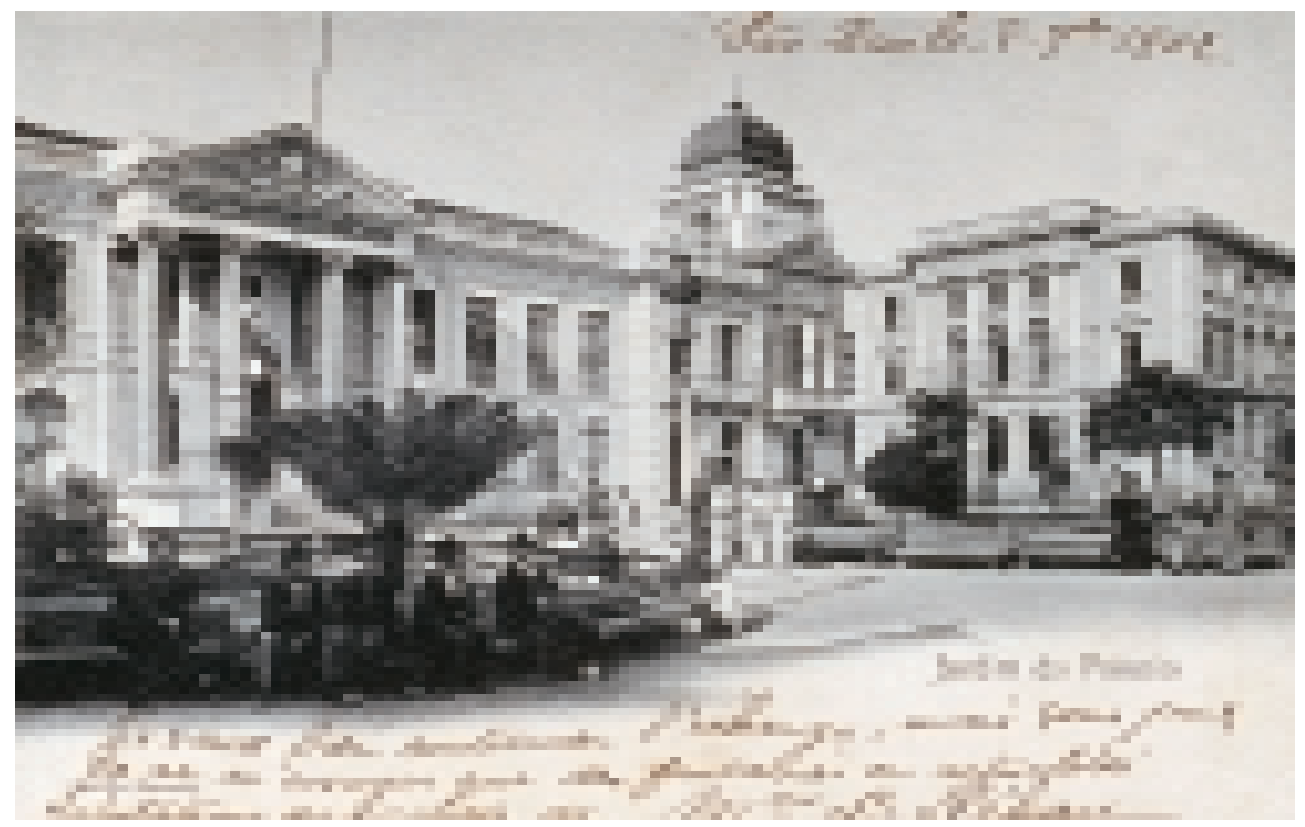

FIGURA 5 - São Paulo, Largo do Palácio, 1902, cartão postal impresso circulado de Guilherme Gaensly. Acervo Museu Paulista da USP. Reprodução de José Rosael. 
Em outro postal de Gaensly, Largo do Palácio (circulado em 1908), a continuidade plástica que o enquadramento das fachadas sugere também está presente (FIGURA 6). Neste caso, temos um espaço vazio cuja delimitação é feita pelos edifícios da Chefatura de Polícia, da Secretaria da Agricultura e do Interior, formando o largo. Assim como o pátio estendia-se como parte da igreja e colégio na configuração anterior, outra praça quadrada surge, só que absolutamente laica. O palácio não aparece na sua íntegra, mas tão-somente o seu torreão, que preenche os quadrantes inferior e superior esquerdos, orientando a leitura da imagem. Este novo elemento arquitetônico acrescido ao palácio, e que ganha destaque nas fotografias de Gaensly, constitui o sinal material da banimento total do Clero deste espaço.

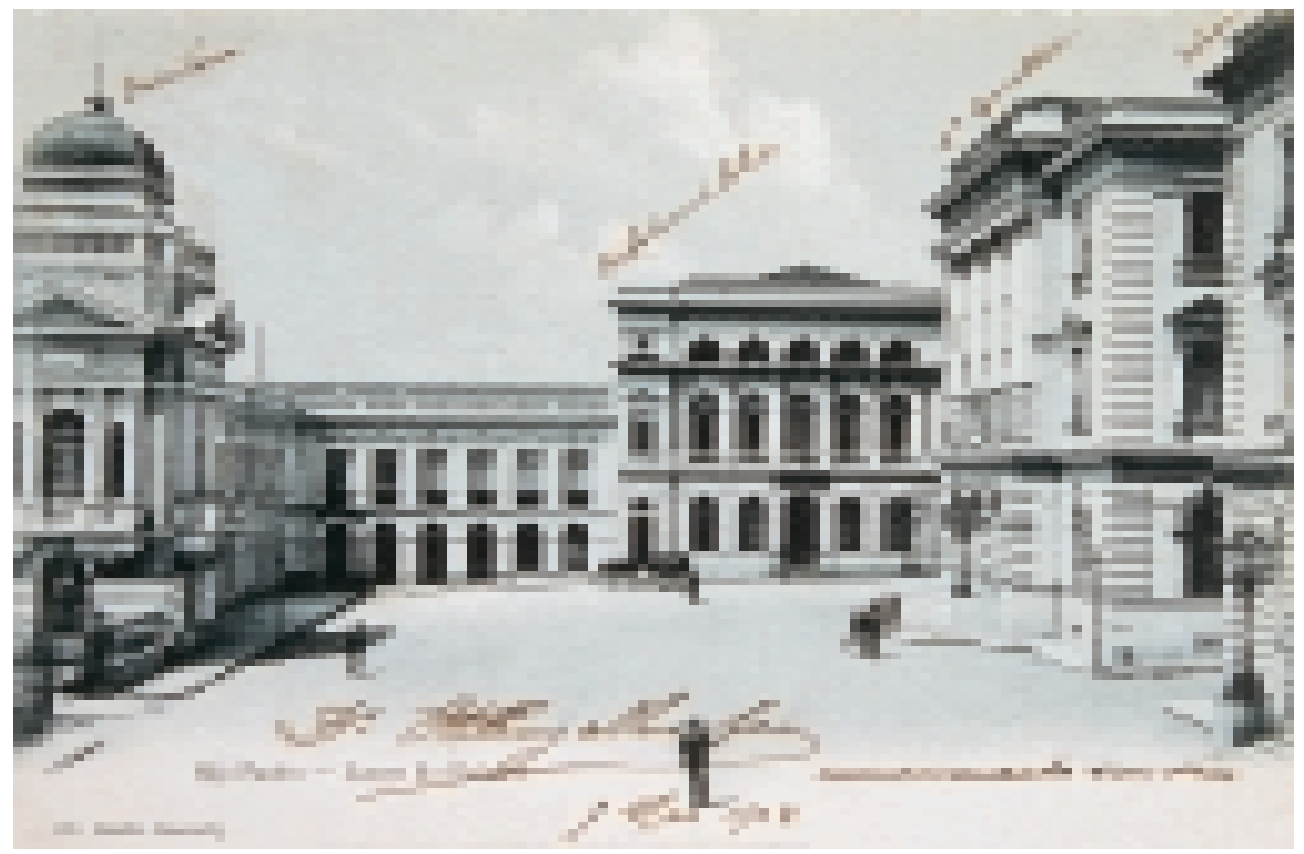

FIGURA 6 - São Paulo, Jardim do Palácio 1908, cartão postal impresso circulado de Guilherme Gaensly. Acervo Museu Paulista da USP. Reprodução de José Rosael.

Após a Proclamação da República, o pátio transformou-se em objeto de disputa entre o Estado e o Clero. O edifício passa a pertencer ao Estado e a igreja é convertida em Palácio do Congresso. Em 1891, o então presidente Jorge Tibiriçá decidiu demolir a capela, idéia contra a qual se rebelaram membros eclesiásticos e de famílias tradicionais da cidade. Não resolvido o impasse, cinco anos depois, devido às péssimas condições de manutenção, a torre da igreja sofreu um desmoronamento, e foi substituída pelo torreão, seguindo o mesmo estilo da fachada principal.

O processo de demolição e retirada dos objetos de valor da capela ficou a cargo de uma comissão formada por D. Joaquim Arcoverde, Toledo Piza e 
Theodoro Sampaio, este último engenheiro encarregado das obras. Os jornais $O$ Estado de S. Paulo e Correio Paulistano informam sobre o debate do momento, que mobilizou moradores contra a decisão do governo. O fotógrafo Pedro Hoenen foi encarregado de acompanhar as obras de demolição, cumprindo uma das funções principais da fotografia nessa época - a documentação de processos de intervenção na cidade, que iria compor relatórios técnicos e administrativos. $\mathrm{Na}$ notícia publicada no O Estado de S. Paulo sobre a demolição da igreja, após aquiescência do bispo e relatório técnico do engenheiro Theodoro Sampaio, tradição, história e monumento são referidos na fala justificadora da ação do Estado quanto à decisão de transferir os restos históricos para o Museu do Estado, o atual Museu Paulista da USP (MELLO; MELLO, 1975, p. 36).

Com a exclusão das funções religiosas devido à demolição da torre e da capela, promoveu-se a primeira lacuna nas significações sociais imediatamente associadas ao pátio - o poder da lgreja na organização da cidade colonial e a lembrança de seus fundadores. Os restos foram transferidos para o museu, o lugar institucionalizado para "guardar" a memória. Nesta ação é possível vislumbrar um primeiro sinal de cooptação de suportes materiais para funcionar como testemunho de uma memória: justamente aqueles objetos envolvidos na prática diária da missa, como o mobiliário da capela (mesa, altar, cruz). De um esvaziamento de práticas começou a se constituir uma tradição que, como veremos mais adiante, daria corpo à visão teleológica de formação da nação.

Com a finalização das obras das Secretarias da Justiça, da Agricultura e da Fazenda, projetadas pelo arquiteto Ramos de Azevedo, e com as alterações arquitetônicas ocorridas na igreja e colégio dos jesuítas, o pátio perdeu totalmente sua expressão como marco religioso, e a área passou a ser conhecida tão-somente como centro político e cívico. Esta é a imagem presente em cartões postais e álbuns fotográficos. Forma sintomática do resultado de uma disputa entre os poderes religioso e laico, na qual este último foi o vencedor. Guilherme Gaesnly, o fotógrafo que nos legou o maior número de fołografias da primeira década do século XX circuladas em cartões postais e em álbuns fotográficos, foi um importante agente da difusão de uma imagem moderna de São Paulo, desenhada pelo poder público, um de seus principais clientes ${ }^{8}$. A exclusão da atividade religiosa, apesar de representar um primeiro esvaziamento social do espaço, não alterava a característica que privilegiava o estar, proporcionada pela praça. Esta particularidade permitia uma aproximação com o poder público executivo, hoje impensável para nós?.

As descrições textuais indicam que as práticas sociais mistas ainda dotavam este espaço de uma rede viva de relações, em que interagiam trabalho e lazer, momentos de baixo uso e ocupação em massa, imagens urbanas do poder público e de lugares antigos, fundantes, enfim um centro emissor de significações:

Muitas das grandes praças da área comercial da cidade são cercadas por bonitos e altos edifícios de construção moderna. No largo do Palácio, como o nome indica, está situado o Palácio do Governo: é um elegante e espaçoso prédio, com belo jardim tropical. O edifício do Tesouro Estadual, as sedes das Secretaria do Interior, da Agricultura, da Justiça e também a do Correio, estão situados no largo. A Tesouraria Geral dá Fazenda é um magnífico edifício de atraente arquitetura e feição distintamente metropolitana. (WRIGHT, 1902 apud BRUNO, 1981).

Os relatos deste século não mais consideram a ocupação anterior, e nem mesmo recorrem à denominação pátio ou colégio. A feição distintamente 
metropolitana, ou a [...] (cidade) de construção moderna, trazia implícito o reconhecimento da mudança como índice positivo, em um tempo em que o novo era mais desejado que o antigo (NORA, 1993, p. 13), identificado com a imagem de cidade arcaica, pobre e nada imponente, dos oitocentos, esta sim, sacralizada no museu ${ }^{10}$. Apesar do esquecimento do antigo, este centro urbano apresentava ainda um equilíbrio de suas funções, onde o jardim do palácio continuava a funcionar como pólo catalisador da representação formal do poder laico e do uso comunitário.

Segundo Segre (1977), o rompimento com este centro emissor de significações para segmentos diversos começou a ocorrer em muitos países latinoamericanos a partir de meados do século XIX. Podemos identificar este processo em São Paulo no início do século XX. As inúmeras reformulações urbanísticas ocorridas nas duas primeiras décadas na região central da cidade contribuíram para modificar a paisagem de sua ocupação inicial. De um modo geral, o planejamento urbano que orientou essas reformulações pretendia melhorar o fluxo viário: ruas foram alargadas e novos viadutos e avenidas surgiram. Entre eles, o Viaduto Boa Vista, ao lado do Pátio do Colégio, cuja construção, apesar de iniciada na década de 1910, só foi finalizada quase vinte anos mais tarde. A "vocação" para a circulação, que iria pouco a pouco se sobrepor a todas as demais atividades concentradas no centro, promoveu um segundo momento de esvaziamento das práticas sociais concentradas no Largo do Palácio.

Talvez como decorrência desse redirecionamento das funções atribuídas ao centro, a residência dos governadores foi transferida para o palacete que o Estado adquirira da família de Elias Chaves, situado na esquina da Alameda Glette com a Avenida Rio Branco, no bairro Campos Elíseos. Nesse período, o edifício do palácio sofreu mais uma demolição: a ala destinada à moradia dos governadores (1908). No antigo palácio continuava funcionando a Secretaria do Interior, onde o governador despachava.

Esta situação perdura até 1930, quando o governador passa a concentrar todas as suas atividades nos Campos Elíseos. Com a transferência definitiva da sede do governo, o palácio passa a ser ocupado pela Secretaria da Educação. O Pátio do Colégio perde então totalmente a sua identidade, pois não representa mais nem mesmo o marco político e administrativo da cidade.

Para garantir o fluxo de circulação possibilitado pelo Viaduto Boa Vista, o último e fatal esvaziamento se deu no Pátio do Colégio: a praça foi banida, substituída pela instalação, em 1925, de um monumento comemorativo da fundação de São Paulo, esculpido em 1913 por Amadeu Zani llália, 1869Brasil, 1944). As práticas relacionadas com o lugar não mais incluíam o estar (a função prazerosa de ouvir a banda, por exemplo). A relação se reduziu a momentos transitórios, e ao espaço público restou a função de estacionamento.

A idéia de ali instalar-se um monumento ${ }^{11}$ é reveladora de um paradoxo: a necessidade de marcar fisicamente o lugar de fundação com um dispositivo de memória coletiva representa, na verdade, o esvaziamento de todas aquelas práticas que dotavam este espaço de sua carga simbólica e ativa em significações e usos. Essa memória de efeméride, reduzida à fruição em trânsito, cumpre uma função pretensamente compensatória da perda que a "vocação" de circulação imputou aos usuários da cidade e desse espaço em particular" ${ }^{12}$.
11. "O monumentum é um sinal do passado.Atendendo às suas origens filológicas, monumento é tudo aquilo que pode evocar o passado, perpetuar recordação... [...] O monumento tem como características o ligar-se ao poder de perpetuação,voluntária ou involuntária, das sociedades históricas (um legado à memória coletiva) [...]" Le Goff, Documento/ Monumento (ENCICLOPEDIA EINAUDI, $p$. 95).

12. Segundo Nora, os monumentos integram a classe de marcos testemunhas de outra era. Marcos comemorativos, bastiões: "Sem vigilância comemorativa, a história rapidamente os varreria [...]. Mas se o que eles defendem não estivesse ameaçado, não se teria, tampouco, a necessidade de construí-los. Se vivêssemos verdadeiramente as lembranças que eles envolvem, eles seriam inúteis. E se, em compensação, a história não se apoderasse deles para deformá-los, transformálos, sová-los e petrificá-los eles não se tornariam lugares de memória. É este vai-e-vem que os constitui:momentos de história arrancados do movimento da história mas que lhe são devolvidos. Não mais inteiramente a vida, nem mais inteiramente a morte, como as conchas na praia quando o mar se retira da memória viva" (NORA, 1993, p. 13). 
Duas fotografias, uma circulada na forma de cartão postal em 1925 e outra original de 1926 (FIGURAS 7, 8) são absolutamente sintomáticas da supremacia da circulação no espaço do pátio. No cartão postal (FIGURA 8), o enquadramento adotado elege o monumento como o ponto central da imagem. O ponto de vista adotado, por sua vez, de uma perspectiva ascendente, agiganta ainda mais o monumento, bem como o edifício no último plano, que sofre inclusive uma ligeira distorção. Neste caso, o contraste de escala com a figura humana no quadrante inferior direito parece indicar formalmente a prerrogativa do monumento no espaço em detrimento de seu uso pelos transeuntes. No original anônimo de 1926, partes de um automóvel e pedestres dão a direção formal a partir do quadrante inferior direito. O equilíbrio dinâmico é alcançado com o contraste entre a direção horizontal sugerida pelo automóvel e a direção vertical representada pelo monumento. Não existe um ponto único de atração na imagem, mas dois - o monumento e o torreão do palácio, que guardam ressonâncias, dotando a imagem de uma tensão formal. Ao contrário do postal de Gaensly, as pessoas aqui são vultos dos quais a câmera só capta 0 movimento.

Em ambas as imagens o edifício encontra-se na sombra, contra a luz, aspecto formal de conteúdo altamente simbólico ou, no mínimo, revelador de que o edifício e seu espaço estendido pelo antigo jardim não mais funcionavam como elemento central.

Uma das especificidades das imagens visuais e textuais aqui analisadas de maneira complementar é a possibilidade que elas nos abrem de atingir o terreno do intangível. Por isso podemos denominá-las imagens-sintoma, na medida em que a abordagem de conjunto pode revelar algumas linhas de força atuantes nas transformações espaciais e de significados sociais deste lugar. A atenção dispensada ao uso da praça nos fala principalmente das relações que ali tinham lugar e da concretização de seus valores e significados sociais, através dos eventos cotidianos e de seu público. Operando, pois, em uma dimensão visual, estes documentos nos informam não só sobre as intervenções arquitetônicas e paisagísticas que transformaram o Pátio do Colégio em Largo do Palácio, mas șobretudo sobre como foram as práticas que lhe deram forma, funções e sentidos. É assim que podemos arriscar um paralelo entre o esvaziamento das múltiplas funções deste espaço e a abordagem formal (realizada de maneira voluntária ou involuntária) das imagens que registram o Palácio do Governo já na década de 1920. Acreditamos que esta abordagem constitui um caminho seguro para alargar o entendimento da cidade segundo as dimensões sugeridas por Meneses (2003) - a cidade como artefato, campo de forças e representações urbanas.

Imagens-vetor

Na década de 1940, as discussões em torno das noções de patrimônio e de preservação arquitetônica eram alimentadas por arquitetos, historiadores e interessados de outras áreas ligados a um movimento de revitalização da arquitetura colonial de São Paulo iniciado já nos anos de 1910, como José Mariano Filho, Ricardo Severo, Wasth Rodrigues, entre outros, que divulgavam suas asserções e estudos na Revista do Patrimônio Histórico e em conferências. Em uma delas, 


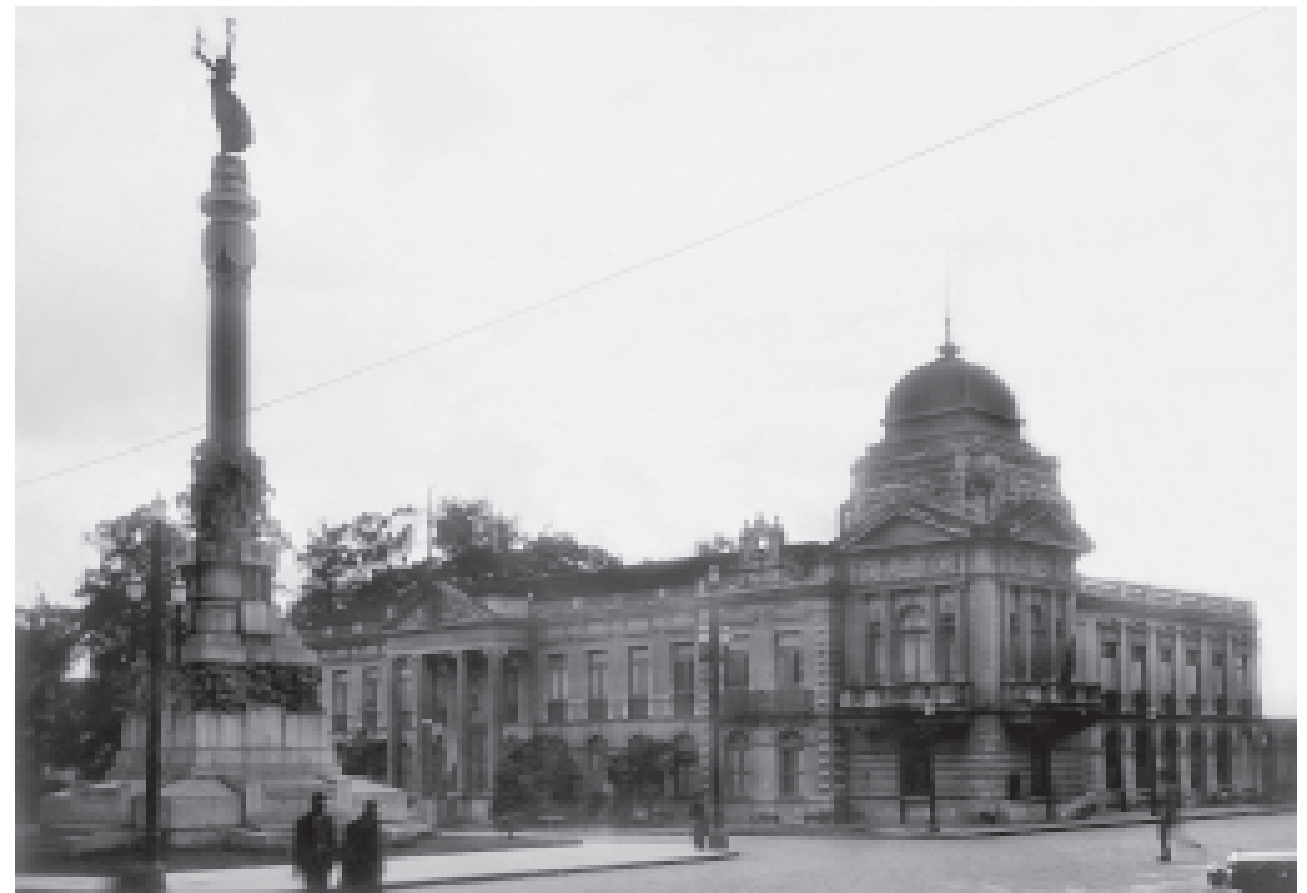

FIGURA 7 - Largo do Palácio, c. 1926, original s/autoria. Acervo Museu Paulista da USP. Reprodução de José Rosael.

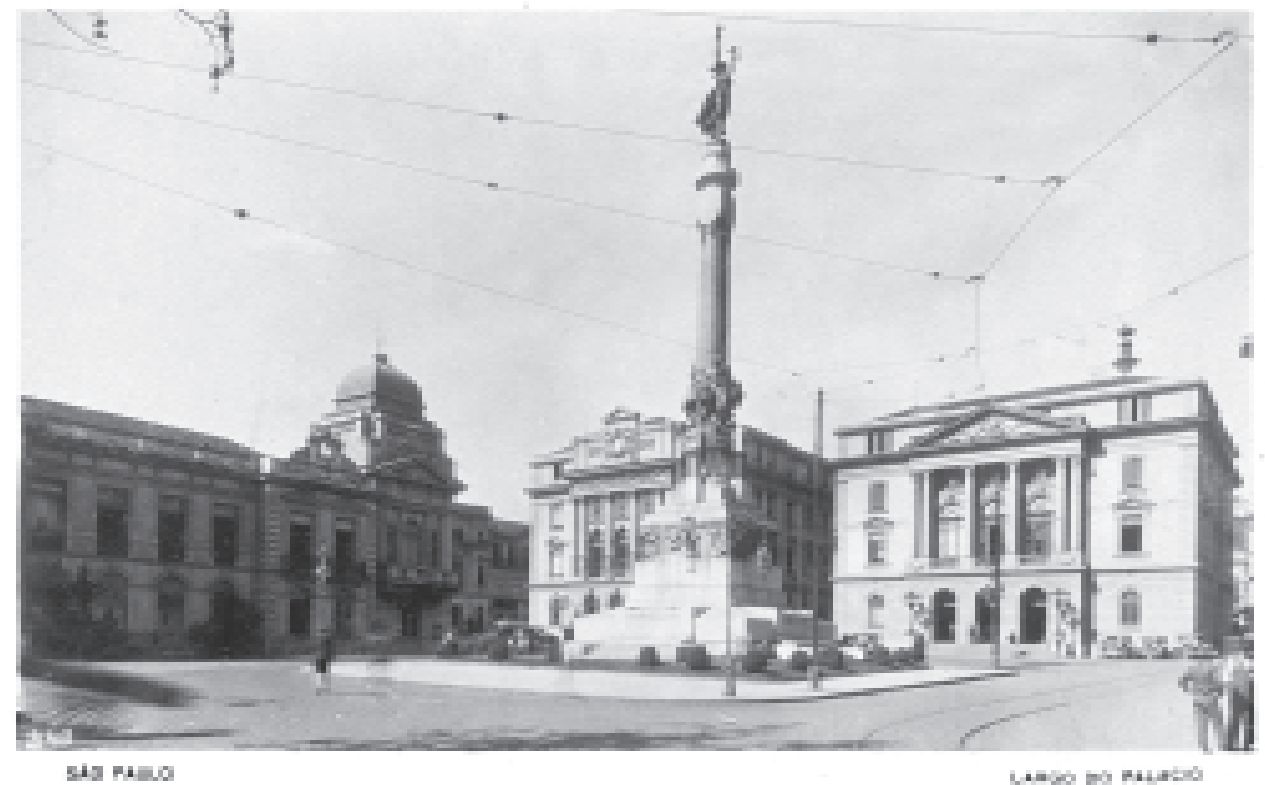

FIGURA 8 - Palácio do Governo, c. 1925, cartão postal fotográfico. Acervo Museu Paulista da USP. Reprodução de José Rosael. 
13.A propósito do problema da autenticidade e patrimônio cultural, Gonçalves afirma que:"A nãoproblematização da categoria autenticidade desempenha um papel importante nessa estratégica retórica.A autenticidade do patrimônio nacional é identificada com a suposta existência da nação como unidade real, autônoma, dotada de uma identidade, caráter, memória, etc. Em outras palavras, a crença nacionalista na "realidade" da nação é retoricamente possibilitada pela crença na autenticidade do seu patrimônio. Não importa que os conteúdos das definições de patrimônio possam variar bastante em termos históricos e sociais".(GONÇALVES, 1988 , p. 268).

14. Carvalho e Lima, 1993, op.cit. proferida por José Mariano Filho no Rotary Club, em 1941, a idéia de recuperação do Pátio do Colégio, nesse momento ocupado pela Secretaria de Educação, é aventada:

Dentre de 13 anos São Paulo comemorará o 4 centenário de sua fundação, seria um ato da mais alta significação cultural a reconstituição integral da igreja dos jesuítas, e uma ala do antigo colégio, exatamente no sítio em que ela existia, de modo a ser novamente, rezada a primeira missa no planalto de Piratininga o pequeno oratório de "paus e barro" construído pelos índios para Joseph de Anchieta. São Paulo tem uma dívida sagrada a resgatar com a Companhia de Jesus. $\bigcirc$ momento é chegado. Si a idéia progredir como é de se supor, dado o entusiasmo com quem tem sido acolhida por todos os intelectuais paulistas, $\bigcirc$ Rotary Club, em cujo seio sempre encontra éco as idéias de interesse social não the negará apoio. A civilização não é obra de uma época. A história de um povo é feita por etapas sucessivas, concorrendo cada geração com seu esforço em pról do bem, da comunhão social. Honrar o passado é dignificar o presente [...]. $\bigcirc$ esquecimento do passado cria uma barreira entre o presente e o futuro. São Paulo deve orgulhar-se do esforço empreendido de seus antepassados. A história de São Paulo está vinculada de modo indelével à Companhia de Jesus. Restituindothe o singelo templo cujo barro das parede, Anchieta socava com as próprias mãos, São Paulo se desagrava da injúria feita a seus benfeitores infatigáveis, àqueles sob cuja proteção desvelada viveram as remotas gerações da terra de João Ramalho. (discurso compilado por CARDIM FILHO, 1975).

O discurso de José Mariano exalta o passado colonial e prega a reconstituição da igreja como forma de criar o elo necessário entre a origem e o futuro. Os processos de ruptura e reorganização social representados pela conformação laica que o locus da fundação adquire no último quartel do século XIX não se ajustam à linearidade imposta pela perspectiva teleológica. Imbutida nas propostas preservacionistas, esta perspectiva justificará a eliminação dos marcos físicos dessa ocupação. Clero e Estado neste momento não mais se antagonizam e irão celebrar, juntos, a fundação da cidade, concentrando na imagem de Anchieta a carga simbólica do mito de origem. A dívida a ser resgatada coloca em evidência não a origem colonial e espoliada de São Paulo, mas a visão sacralizadora da ação jesúítica. A reconstrução do pátio, transformado em monumento-réplica, serve aqui como marco da dimensão temporal da nação. O passado faz-se presente na representação do partido arquitetônico tomado mais de fotografias e desenhos do que das evidências arqueológicas; ensaia-se uma experiência de autenticidade a partir da reconstituição ${ }^{13}$.

O problema de esvaziamento do espaço como lugar de práticas e produção de sentidos múltiplos não fazia parte do tipo de enfoque desta geração. A tônica recaía, sobretudo, na recuperação do locus de fundação da cidade, em associações que pretendiam traçar um continuum capaz de garantir a memória da formação da nação em seu segmento paulista. Essa visão encetada por uma consciência preservacionista - despertada, talvez, pelas incessantes e celebradas alterações físicas da região central, lidas e tidas como sinais de progresso e crescimento econômico - irá tomar corpo entre tradicionalistas da elite paulistana.

Este uso dos documentos iconográficos repousa sobre antecedentes sólidos, como a exposição relativa à cidade de São Paulo concebida por Affonso de E. Taunay para ocupar as salas históricas do Museu Paulista ${ }^{14}$. As fotografias de Militão serviram também de referência para a encomenda de pinturas e para a confecção da maquete São Paulo em 1841, ainda hoje em exposição. A reconstituição da cidade colonial desaparecida começara, portanto, no espaço museológico para ganhar a cidade em função das atividades em torno da comemoração do IV Centenário da Cidade de São Paulo. 
Carlos Alberto Gomes Cardim Filho, engenheiro-arquiteto e professor da Faculdade de Arquitetura e Urbanismo, foi um dos importantes agentes deste processo. Era de sua autoria e de Luciano Octávio Gomes Cardim o estudo e projeto de reconstrução da igreja, para o qual:

Podemos com documentos iconográficos e de textos existentes reconstruíla e, dentro do quadro urbanístico do local, com engenho e arte, haveremos de enquadrar a lgreja de forma a ficar marcado o palmo de terra da nossa origem de cidade grandiosa. (PAULISTÂNIA, 1954, p. 36).

Fazem parte do conjunto de documentos iconográficos aos quais Gomes Cardim recorre a fotografia de autoria anônima de 1860 (FIGURA 9), o já referido desenho de Thomas Ender, e principalmente a série de fotografias de autoria de Pedro Hoenen, que documenta a demolição da igreja em 189715.

No longo artigo do qual extraímos o trecho acima, Gomes Cardim fornece um histórico das negociações envolvendo o poder público, o Clero e
15. Uma fotografia desta série foi reproduzida em tela por Jonas de Barros (Ruínas da Igreja do Colégio, 1896, óleo sobre tela, $600 \times 355 \mathrm{~mm}$ ), segundo encomenda de Affonso de E.Taunay, e integra o acervo do Museu Paulista da USP.

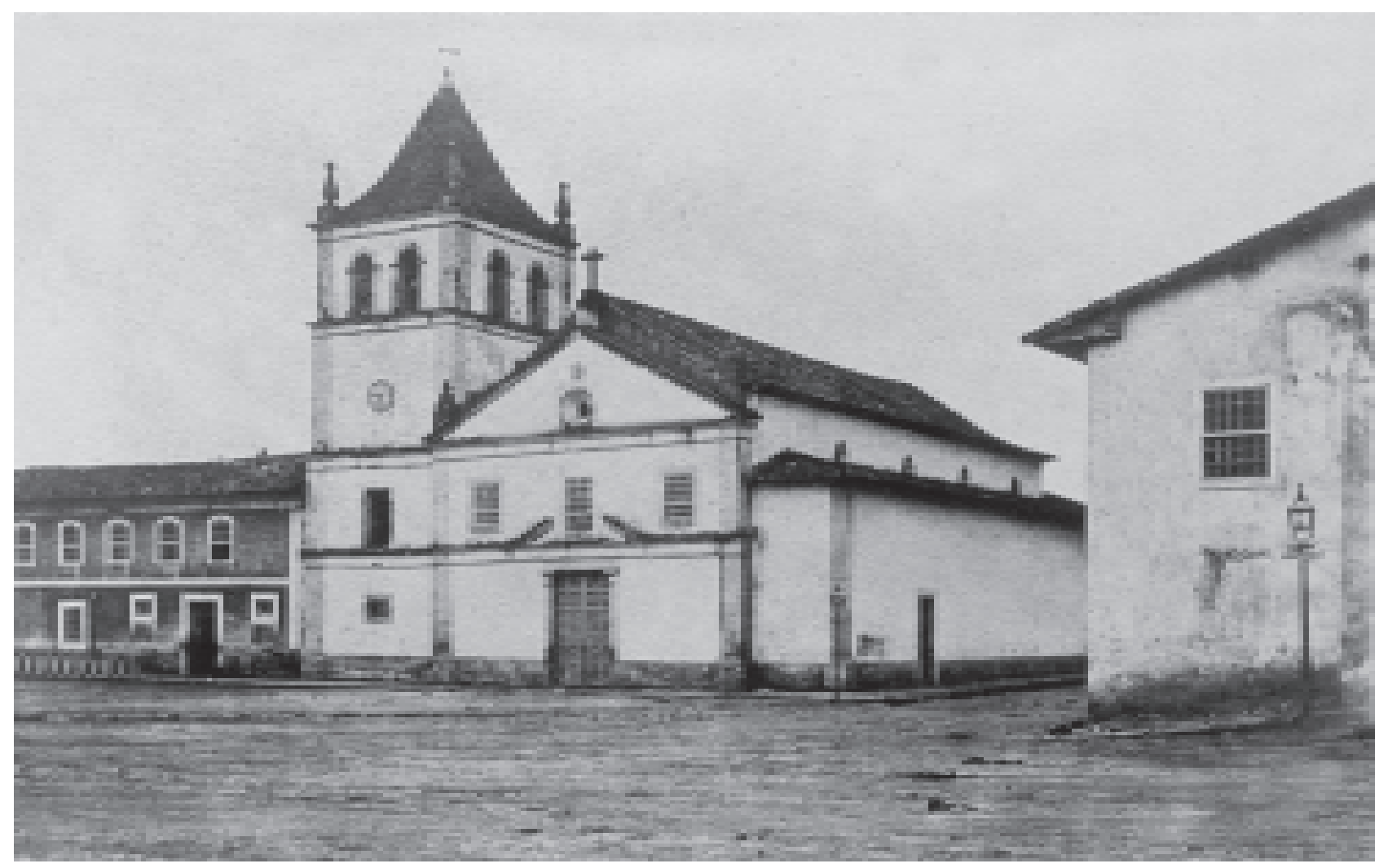

FIGURA 9 - Igreja do Pátio do Colégio, original s/autoria, c. 1860. Acervo Museu Paulista da USP. Reprodução de José Rosael. 
setores da sociedade que culminaram com a demolição do Palácio do Governo em 1953, a descoberta dos vestígios da construção de taipa precedente e o movimento em prol de uma urbanização deste espaço. Na verdade, esta mobilização teve início em 1945 com a coleta de 4.000 assinaturas em um "livro de ouro", solicitando o restabelecimento do colégio, entregue ao então interventor de São Paulo, Dr. Fernando Costa. Esquecido nos arquivos governamentais, este documento reapareceu em 1953 e acabou funcionando como lastro para o projeto e, portanto, vetor de ações e leis que finalmente levaram a cabo a idéia de reconstituição. As dimensões políticas da ação cultural aí se estabelecem: a aliança com a lgreja e a monumentalização de um espaço são referenciadas pela coletividade (simbolicamente representada pelo livro de ouro e suas 4.000 assinaturas) e apontam um caminho seguro que permite construir uma tradição sem conflitos capaz de fornecer as bases simbólicas para a nacionalidade: "É a tradição de São Paulo ostentando restos de construções históricas. A tradição sempre foi base segura de uma nacionalidade. Povo sem tradição não se impõe no conceito universal das Nações [...]" (CARDIM FILHO, 1954, p. 36).

A função da tradição nesse trecho é clara: permite ao povo impor-se perante outras nações, ou seja, fornece uma identidade coletiva, ainda que celebrada por uma memória oficial, capaz de diferenciar o "nosso" povo.

Demais trechos do artigo dedicado ao Pátio do Colégio revelam, ainda que discretamente, outros interesses promotores da nobre missão de resgate da História de São Paulo. O discurso de Toledo Piza, reproduzido no artigo de Gomes Cardim, que insiste em chamar o Pátio do Colégio de monumento, defende a sua urbanização por ter sido ele "desfigurado com construções, que tiraram completamente o sentido histórico do local". Mas curiosamente a proposta de urbanização defendida prioriza a ampliação do local, de modo a dar maior visibilidade à futura réplica da igreja, e sobretudo visando à construção de uma praça cuja função seria:

\footnotetext{
A existência dessa segunda praça, que seria a maior de S. Paulo, facilitaria, também a possibilidade de se localizar, em um de seus ângulos, veículos particulares e de aluguel, evitando a utilização da praça da Sé, que urge ser ajardinada. (TOLEDO PIZA, apud CARDIM FILHO, op. cit.).
}

A necessidade de espaços para estacionamento de veículos não parece contrariar a reconstrução do monumento colonial. Ironicamente, a praça para veículos é o único elemento que de fato guarda vínculos com a trajetória deste espaço que, a partir da década de 1920, transforma-se em área de circulação e estacionamento. Ou seja, apesar do cenário histórico pretendido, as funções de circulação não podem ser preteridas.

A conclusão do artigo de Gomes Cardim nos fornece mais elementos para entender as contradições inerentes às iniciativas deflagradas sob o signo da efeméride: "Com êsse novo estudo, o local ganharia em aspecto paisagístico, ampliando-se também e dando-se-lhe por outro lado, uma utilização mais racional, de acôrdo com o seu duplo valor histórico e imobiliário." (CARDIM FILHO, op. cit.).

Os resultados do estudo - ganho nos aspectos paisagísticos e uso racional - fazem parte de uma retórica que desde o início do século XX justifica as 
intervenções urbanísticas na área central de São Paulo. $\bigcirc$ ganho paisagístico pode ser interpretado como o tratamento estético voltado para a fruição visual da cidade (distante, portanto, das práticas sociais originárias do espaço colonial), equivalendo-se aos termos embelezamento e aformoseamento, termos em voga nos discursos circulados nas matérias da imprensa e presente nos relatórios do poder público ao se referirem às mudanças na cidade. A utilização do termo racional aparece como uma qualidade a priori e nos remete a uma instância técnica, um saber especializado de resolução dos problemas que afetam a cidade. Confere, assim, uma autoridade que exclui quaisquer outras abordagens - de cunho social ou político, por exemplo.

investimento na aparência e no uso racional atendem aos quesitos de valorização deste espaço - a história e a especulação imobiliária. E aqui nos deparamos com uma idéia no mínimo contraditória. A valorização imobiliária de várias áreas de ocupação oitocentista foi a grande responsável pelo desaparecimento de muito edifícios de "valor histórico". Esta maneira "duplipensar" de tratar a questão, parafraseando George Orwell'16, naturaliza um processo selvagem e desordenado de crescimento urbano, regido pela lógica do capital privado.

A contraditória relação com o passado e o progresso de São Paulo é característica não só do artigo de Gomes Cardim mas, na verdade, de toda a revista Paulistânia ${ }^{17}$ em seu número dedicado às comemorações do IV Centenário de São Paulo. Fartamente ilustrada, além das matérias de cunho histórico (A Evolução do Transporte na Paulicéia, Como surgiu São Paulo de Piratininga, ou Urbanização Antiga, entre outros), a revista conta com seções dedicadas à fruição visual de fotografias e desenhos da cidade. São Paulo de ontem [...] São Paulo de hoje - Portfólio de aspectos do passado e do presente da Capital Bandeirante reúne fotografias, reproduções de pinturas e desenhos bico de pena de logradouros paulistanos acompanhados de textos-legenda focalizando algum aspecto pitoresco, como a origem do nome, ou dados históricos de construção deste ou daquele edifício. $\bigcirc$ portfólio traz na abertura um desenho em bico-de-pena baseado na mesma fotografia do Pátio do Colégio utilizada por Cardim Filho para o seu estudo de reconstrução, e a narrativa inicia-se com o Largo da Sé para terminar com fotografias aéreas e uma noturna da área do Anhangabaú, aglutinando fotografias de Militão, outras integrantes dos álbuns comparativos produzidos na gestão de Washington Luiz na Prefeitura (1914-1918), que servem de contraponto às imagens de 1954.

No segundo porffólio da revista, São Paulo de ontem...São Paulo de hoje (III), o subtítulo já não é o mesmo, e sim Portfólio de desenhos e fotografias que documentam o crescimento vertiginoso da capital Bandeirante. Memória do passado no primeiro caso, e documento de um processo no segundo, as imagens selecionadas são ao mesmo tempo objeto de manipulação porque deslocadas de um circuito para outro (do álbum de Militão editado em 1887, por exemplo) e vetores de representações ativas nessa dinâmica urbana. No segundo portfólio, os textos-legenda já não mais focalizam um logradouro em particular, mas apresentam tabelas que provam o crescimento vertiginoso do número de construções. Fotografias da área central predominam, mas não em tomadas pontuais como no primeiro portfólio, e sim em panorâmicas genéricas que comprovam a existência de arranha-céus. Sob o título São Paulo, a cidade que mais cresce no mundo, um dos textos-legenda
16. Em sua obra 1984 , o autor cria o duplipensar para designar a naturalização da coexistência de funções ou atitudes opostas por parte das instâncias de poder que governavam Oceania, país imaginado e totalmente controlado pela figura do $\mathrm{Big}$ Brother.

17. A revista Paulistânia era uma publicação do Clube Piratininga (fundado em 1934). O clube, que oferecia desde excursões turísticas até conferências com oradores de renome, além de palestras sobre arte, torneios esportivos e bailes de gala, tinha como sócios membros da elite paulistana, como podemos aferir pela exaustiva lista nas últimas páginas da revista com os nomes dos 665 sócios-fundadores. 
18. Meneses analisa, a propósito da categoria cultura tal como hoje é entendida, o caráter restritivo de seus usos:"Com efeito, nossa sociedade formulou conceitos restritivos e deformantes de cultura, de valores culturais, de bens culturais, que se projetam também num certo tipo específico de 'uso', restritivo e gerador de deformidades, ainda que apresentado como nobilitante, mas, na realidade, desqualificador de outros usos e funções" (MENESES, 1996, p. 87). informa, por exemplo, que "das antigas casas com beirais debruçados sobre os passeios, estão hoje surgindo edifícios de grande estrutura e importante aspecto". E conclui: "Exemplos dos mais expressivos são as fotografias destas páginas." Igualmente, o artigo sobre o Pátio do Colégio conta com inúmeras fotografias, todas da igreja, porém anteriores à sua demolição em 1897.

História e passado figuram na revista como narrativas pitorescas ou descritivas. As imagens textuais e visuais no caso já são suficientes para se considerar este passado preservado. Daí a tranqüila convivência das imagens de Militão e do "paliteiro de edifícios arrojados" que por sobre o mesmo território se elevou. $\bigcirc$ lamento pelo desaparecimento do Pátio do Colégio é a exceção, por ser ele e somente ele o locus destinado a encerrar simbolicamente toda esta história em sua configuração apenas cênica.

A demolição do palácio (1953) seguiu-se a restituição dos terrenos por ele ocupados para a Companhia de Jesus. Uma campanha coordenada pela Igreja - a Campanha da Gratidão - conseguiu reunir verbas para a reconstrução da antiga edificação. Em 1956, uma cerimônia marcou a data de início das obras, com a assinatura, pela Prefeitura, das plantas dos edifícios que comporiam o conjunto. Na fotografia publicada no álbum Isto é São Paulo, a igreja lá está, branca como um cenário em peculiar enquadramento em que figura em último plano, precedida pelos carros estacionados ou em circulação que dominam o primeiro plano, e o monumento a Anchieta no plano médio hierarquizando o arranjo (FIGURA 10).

Essa espetacular movimentação em torno do encontro com o passado na qual a fotografia atua ativamente tem contornos pedagógicos: a inculcação de uma identidade coletiva, encarnada em "rituais de uma sociedade sem ritual" (NORA, 1993, p. 13). A inserção do marco de fundação na categoria de monumento não implica reconhecer a sociabilidade perdida com o processo de mercantilização do espaço, e sim instituir um sinal capaz de reverter o esquecimento que ele acarretou. Essa lembrança institucionalizada decorre de uma visão elitista de cultura, que não a entende como campo de operação de um conjunto de práticas relacionadas ao trabalho, ao ócio, à crítica, enfim, à fruição em diversos níveis. De monumento, o passo seguinte é a transformação do lugar em museu ou centro cultural, ou seja, dedicado a uma atividade "cultural"18.

Em sentido oposto, o "monumento" inscreve não a sociabilidade e sim a história oficial num espaço consagrado à memória. Na figura do padre Anchieta, esse resgate de um bem cultural pretende uma harmonização - é, como no discurso de José Mariano, o resgate de uma dívida, uma proposta de integração com o gerador da nação paulista. A recriação do passado a partir de um idealizado momento fundante, eliminando os traços materiais do processo de uso desse mesmo espaço nos últimos 130 anos, sugere uma ação apaziguadora, compensatória da espoliação das práticas que culminou no esvaziamento de sentido de um espaço secular.

Com a chegada do metrô na década de 1970, a área foi reurbanizada pela Emurb - Empresa Municipal de Urbanização - e as obras de reconstrução da igreja foram finalizadas pela Sociedade Brasileira de Educação, ligada à ordem dos jesuítas. A semelhança arquitetônica, no entanto, não foi suficiente para a recuperação das práticas que consubstanciaram os valores atribuídos a esta área (FIGURA 1 1). O Pátio do Colégio não logrou escapar da tendência geral de deterioração dos espaços públicos (MENESES, 1992). 


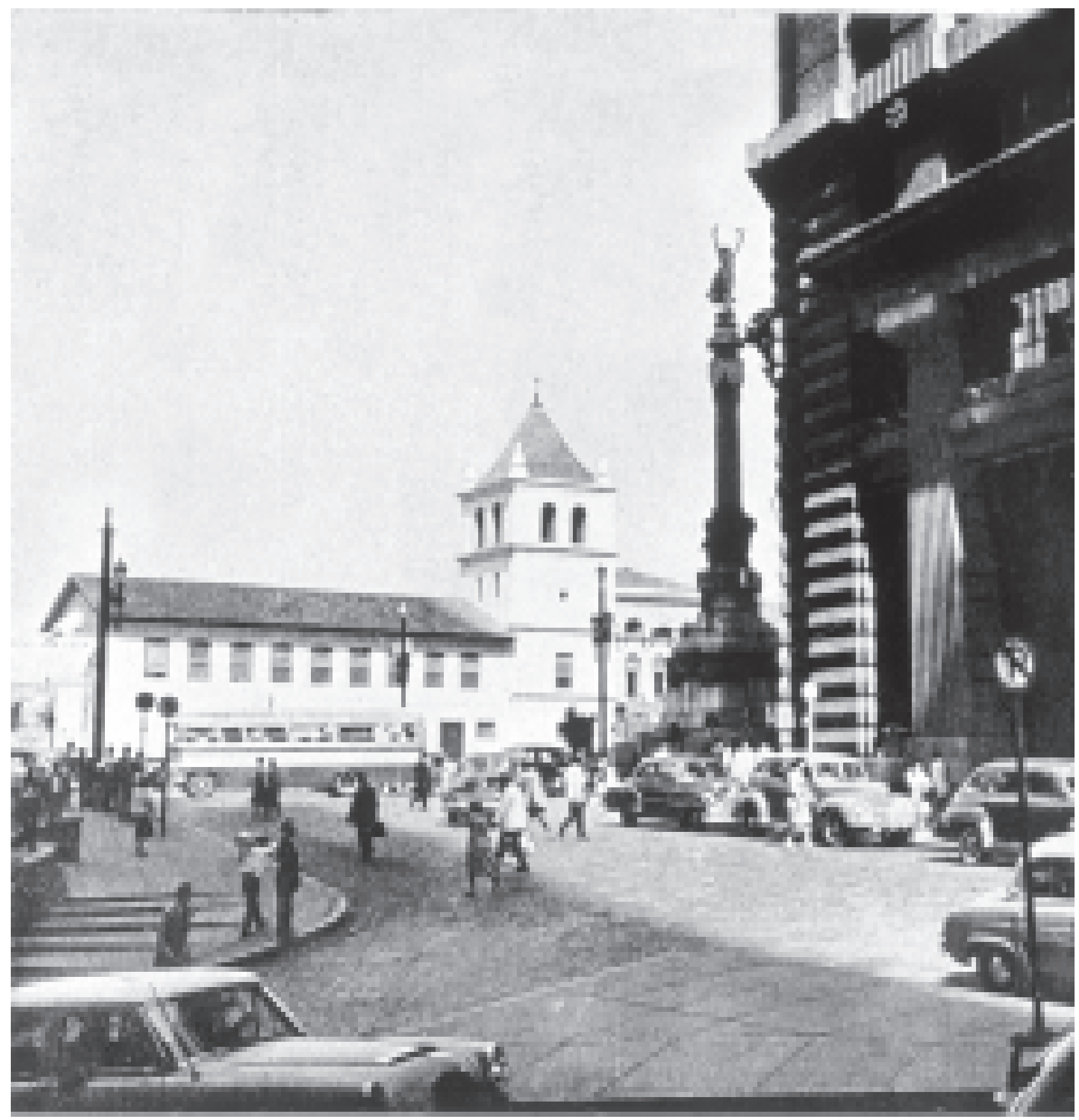

FIGURA 10 - Isto é São Paulo. São Paulo: Melhoramentos, 1956, p. 102. Acervo Particular. Reprodução de José Rosael. 
Para além da réplica, contudo, restou como documento, embora pouco valorizado, a posição geográfica deste sítio urbano, capaz de informar sobre o papel de dominação e proteção desempenhado pela edificação jesúítica sobre seu território. Tal como a descreveu Saint Hilaire, em 1819.

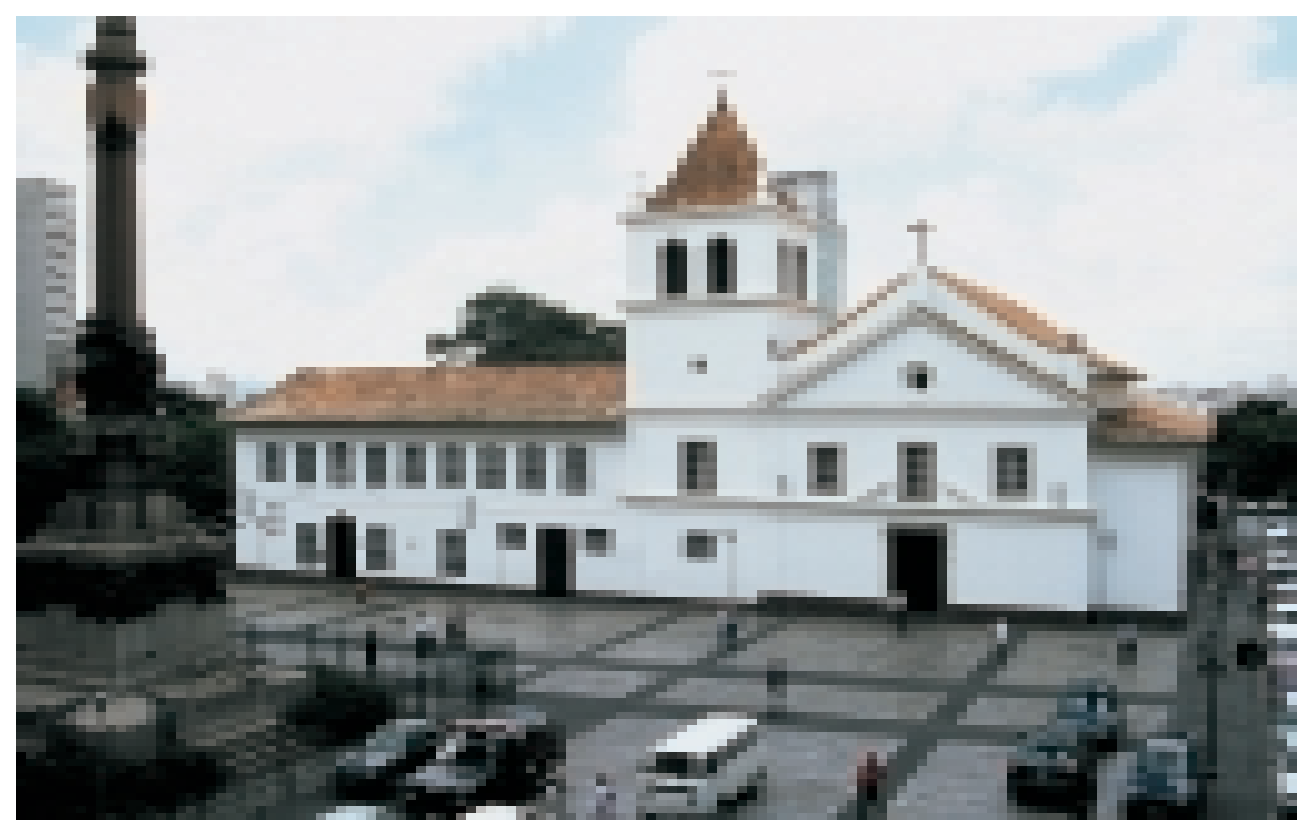

FIGURA 11 - Pátio do Colégio, 1997. Fotografia de José Rosael.

\section{REFERÊNCIAS}

BREFE, Ana Claudia. Um lugar de memória para a nação; O Museu Paulista reinventado por Affonso d'Escragnolle Taunay (1917-1945). Tese (Doutorado). Campinas: Unicamp, 1999.

BRUNO, Ernani da Silva. Depoimento de moradores e visitantes/1553-1958. Registros 4. São Paulo: SMC, 1981.

CAMPOS JÚNIOR, Eudes de Mello. Arquitetura paulista sob o império: aspectos da formação da cultura burguesa em São Paulo. 1997.811 f.Tese (Doutorado) - Faculdade deArquitetura e Urbanismo, Universidade de São Paulo, São Paulo, 1997.

Palacetes paulistanos: a evolução do ambiente doméstico sob o Império. Historical Archeology in Latin America, Columbia, USA, n. 6, p. 89-103, Jan. 1995.

CARDIM FILHO, Carlos Alberto Gomes. Pátio do Colégio. Paulistânia, n. 50, p. 33-36, jan.jun. 1954. 
CARVALHO, Vânia C. de; LIMA, Solange F. de. Fotografia e cidade. Da razão urbana à lógica de consumo. Campinas: Mercado de Letras, 1997.

São Paulo Antigo, uma encomenda da modernidade.As fotografias de Militão nas pinturas do Museu Paulista.Anais do Museu Paulista - História e Cultura Material, Nova Série, São Paulo, v. 1, n. 1, p. 147-174, 1993.

CHASTEL, André. La notion de Patrimoine. In: NORA, Pierre (Org.). Les lieux de memoire. Paris: Gallimard, 1986. v. 2, p. 405-449.

FERRAZ, Vera Maria de Barros (Org.). Imagens de São Paulo: Gaensly no acervo da Light, 18991925. São Paulo: Fundação Patrimônio Histórico da Energia de São Paulo, 2001.

GONÇALVES, José Reginaldo. Autenticidade, Memória e Ideologias nacionais. 0 problema dos patrimônios culturais. Estudos Históricos, Rio de Janeiro, v. 1, n. 2, p. 264-275, 1988.

KOSSOY, Boris. São Paulo, 1900. São Paulo: CBPO/Kosmos, 1988.

LE GOFF,Jacques. Documento/Monumento.In:ENCICLOPÉDIA EINAUDI, v. Memória-História.Lisboa: Impressa Nacional - Casa da Moeda, 1984. p. 95-104.

LEITE,Aureliano. O Colégio do Jesuítas. Revista do Arquivo Municipal, v. 187, p. 73-76, jan.-dez. 1975.

MARTINS, Ana Luisa; BARBUY, Heloisa. Arcadas: história da Faculdade de Direito do Largo de São Francisco, 1827-1997. São Paulo:Alternativa Serviços Programados, 1998.

MELLO,Alexandre; MELLO, Nilva R.Vida e Morte da Igreja do Colégio.Revista do Arquivo Municipal, v. 187, p. 19-39, jan.-dez. 1975.

MENESES, Ulpiano T. B. de. O patrimônio cultural entre o público e o privado.Anais do Congresso Patrimônio Histórico e Cidadania, São Paulo, p.189-194, 1992.

. Os "usos culturais" da cultura. Contribuição para uma abordagem crítica das práticas e políticas culturais (conferência). In:YÁZIGI, Eduardo; CARLOS,Ana Fani A.; DA CRUZ, Rita de Cássia A. (Org.). Turismo: espaço, paisagem e cultura. São Paulo: Hucitec, 1996. p. 88-99.

.A Cidade como Bem Cultural.Patrimônio Cultural. Práticas, métodos, políticas, São Paulo (CONDEPHAAT), n. 1, 2003. No prelo.

NORA, Pierre. Entre Memória e História - a problemática dos lugares.Tradução de Yara Aun Khoury. Traduções. Projeto História, São Paulo, v. 10, p. 7-29, dez. 1993.

OBRAS de arte em logradouros públicos de São Paulo - Regional Sé. Registros 11. São Paulo: SMC, 1987.

SAINT-HILAIRE,Auguste de. Viagem à província de São Paulo. São Paulo: Edusp, 1976.

SEGRE, Roberto. Estructures ambientales de América Latina. Mexico: Siglo Veintiuno, 1977. 


\section{ACERVOS}

Coleção de cartões postais, fotografias avulsas e telas do Museu Paulista da USP.

AZEVEDO, MilitãoAugusto de.Álbum comparativo da Cidade de São Paulo. 1862-1887. São Paulo: [s.n.], 1887.60 fotografias originais.

ÁLBUM Comparativo da Cidade de São Paulo até o Anno de 1916. Organizado por Washington Luiz Pereira de Souza, São Paulo: [s.n.], [s.d.]. 2 v. 112 fotografias originais.Acervo Biblioteca Municipal Mário de Andrade.

ÁLBUM Lembrança de São Paulo III. São Paulo: Rothschild, c[1911]. 39 fotografias originais.Acervo Biblioteca Municipal Mário de Andrade.

ISTO É São Paulo. 104 flagrantes da Capital Bandeirante. 4a. ed. São Paulo: Melhoramentos, [1953]. 104 fotografias impressas em preto e branco.Acervo Biblioteca Municipal Mário de Andrade.

REVISTA Paulistânia, São Paulo, n. 50, jan.jun. 1954.

VUES de São Paulo. Comissariat Général de L'État de São Paulo, 1911.99 fotografias impressas. Acervo Biblioteca Municipal Mário de Andrade.

Artigo apresentado em 8/2003. Aprovado em 8/2003. 
but also the images of the city that have been made from this point of view. We have chosen to analyze some images of this area, focusing on the end of the century, in a counterpoint to works depicting the same region by chroniclers, journalists and memorialists, in an attempt to understand a little more about the society that had produced them.

KEYWORDS: Urban Views. Representation. Urbanization. São Paulo. Iconography.

Anais do Museu Paulista. São Paulo. N. Sér. v. 6/7.p. $37-59$ (1998-1999). Editado em 2003.

Pátio do Colégio, Largo do Palácio

Solange Ferraz de Lima

Oartigo focaliza a trajetória do Pátio do Colégio, espaço que integra o conjunto de bens culturais da cidade de São Paulo, a partir da produção iconográfica que o tem como tema e referências aos seus usos e configuração espacial em crônicas e descrições de viajantes, no período compreendido entre 1860 e 1956. A visualidade, campo de interação entre o objeto, sua representação e sua recepção, é aqui entendida como uma das dimensões da sociedade. Nesta perspectiva, a análise empreendida abarca niveis distintos de interpretação das relações entre o espaço urbano e o documento visual, partindo do pressuposto de que a produção iconográfica de paisagens urbanas é parte integrante e ativa da produção social da cidade. Procura-se demonstrar como as imagens urbanas resultantes deste conjunto de referências iconográficas e textuais atuam como sintomas e vetores das transformações ocorridas no Pátio do Colégio.

PALAVRAS-CHAVE: São Paulo. Pátio do Colégio. Representações urbanas. Cultura material.Visualidade.

Anais do Museu Paulista. São Paulo. N. Sér. v. 6/7. p.61-82 (1998-1999). Editado em 2003.

Pátio do Colégio, Largo do Palácio

Solange Ferraz de Lima

The article focuses on Pátio do Colégio, one of the places that make part of São Paulo's cultural heritage, departing from the iconographic documentation concerning this area and also references to their uses and the spacial configuration in chronics and descriptions by the travellers in the period between 1860 and 1956. The visuality, a field of interaction between object, its representation and its reception, is here understood as one of the dimensions of society. From this perspective, the analysis concerns different levels of interpretation of the relations between urban space and visual documentation, starting from the idea that the urban landscapes' iconographic production is an integral and acting part in the city's social production. We try to show the way the urban images emerged from the iconographic and textual references have an active role as symptoms and vectors of the transformations occurred in the Pátio do Colégio.

KEYWORDS: São Paulo. Pátio do Colégio. Urban Representations. Cultural Material.Visuality.

Anais do Museu Paulista. São Paulo. N. Sér. v. 6/7. p. 61-82 (1998-1999). Editado em 2003.

Circulação da obra de arte no período da Belle Époque paulistana

Mirian Silva Rossi / Programa de pós-graduação da FFLCH/USP

Este artigo trała de alguns dos principais aspectos que dizem respeito às inter-relações que a práxis artística mantinha com os circuitos de circulação e mediação da obra de arte, no período conhecido como Belle Époque. A emergência de fenômenos específicos ligados ao campo em causa foi favorecida pelo ambiente de mudanças profundas, nos mais diversos níveis, que se instaurara na capital paulista em decorrência da Proclamação da República, do desenvolvimento da lavoura cafeeira e do crescimento da indústria. $\bigcirc$ amplo circuito que se formou em torno da arte, aqui exemplificado pelas exposições e pelos espaços de exposição permitiram apreender os principais elementos constitutivos do campo artístico paulistano em seu momento de nucleação original.

PALAVRAS-CHAVE: São Paulo. Campo artístico. Cultura material. Mercado de arte.

Anais do Museu Paulista. São Paulo. N. Sér. v. 6/7.p. 83-119 (1998-1999). Editado em 2003.

Circulation of the work of art in the Belle Époque period in São Paulo 